\title{
In the Land of the Dammed: Assessing Governance in Resettlement of Ghana's Bui Dam Project
}

\author{
Kwabena Asiama *, Monica Lengoiboni and Paul van der Molen \\ Faculty of Geo-Information Science and Earth Observation (ITC), University of Twente, \\ 7500AE Enschede, The Netherlands; m.n.lengoiboni@utwente.nl (M.L.); pvdmolen01@hetnet.nl (P.v.d.M.) \\ * Correspondence: k.o.asiama@utwente.nl or kwabena.asiama@gmail.com; Tel.: +31-53-489-6183
}

Received: 25 September 2017; Accepted: 31 October 2017; Published: 10 November 2017

\begin{abstract}
Resettlement resulting from dam construction has raised several concerns due to the negative aftermath impacts. In Ghana, the construction of three hydroelectric dams resulted in large-scale resettlements. Given the little experience that Ghana has in resettlements, it is necessary for a robust monitoring structure for resettlements. However, this was not available in the last resettlement undertaken for the Bui Dam Project. This paper aims at developing an assessment framework for monitoring resettlement activities on customary lands from a good governance perspective. Based on four good governance principles, transparency, public participation and inclusiveness, equity and rule of law and accountability, a good governance assessment framework is built and applied to the Bui Dam Project using a case study approach. Data were collected through interviews and focus group discussion with the key actors of the resettlement project. It was first found that the planning stage of the resettlement came out with a robust plan that was to prevent the impoverishment of the affected persons. However, in the implementation of the resettlement, not all good governance principles were adhered to. In conclusion, it was found that by deconstructing the resettlement process with a good governance framework, the problematic areas of the resettlement can be effectively differentiated between the planning and implementation phases.
\end{abstract}

Keywords: resettlement; compulsory land acquisition; governance; dam construction; customary lands

\section{Introduction}

Resettlement as a form of compensation for compulsory land acquisition has raised several concerns especially with regards to the negative aftermath impacts on the affected communities [1-4]. The underlying justification for undertaking resettlement is to acquire land in the public interest towards sustainable development. However, in spite of a careful and inclusive planning process, resettled populations are often left worse off than they were prior to the resettlement $[5,6]$. This challenges the sustainable development rationale for land acquisition that precedes resettlement. Since the Ghanaian government's aim to increase providing key basic infrastructure to improve livelihoods, health care and energy supply largely includes the compulsory acquisition of large tracts of land, it is essential to explore how these land acquisitions and their resettlements will also be turned into development opportunities. This paper presents a framework for the assessment of good governance in the undertaking of resettlement activities as part of a dam construction in Ghana.

Although compulsory land acquisition has been used to acquire public lands in Ghana since 1850, few have resulted in resettlement as a form of compensation $[7,8]$. The construction of all three hydroelectric dams in Ghana resulted in resettlement: the Akosombo Dam (1965-1968), which displaced 80,000 people, the Kpong Dam (1978-1981), which displaced 6000 people, and the most recent being the Bui Dam (2008-2013), which displaced 1200 people $[3,9,10]$.

A recently constructed dam is the Bui Dam Project (BDP) in Ghana funded by the Government of the People's Republic of China under an Engineering, Procurement and Construction contract, 
at the tune of 1.2 billion dollars [11]. The construction of the dam was undertaken by the Chinese construction company Sinohydro, while the other social and resettlement aspect of the project was handled by the Ghanaian government as with similar Sino-funded hydro-electric dam projects in other parts of the world [12,13]. In line with the practices of the World Bank and other multilateral financers, a Resettlement Planning Framework (RPF), a forerunner to a binding Resettlement Action Plan (RAP), was formulated to guide the resettlement process. Previous studies on the Bui Dam have largely focused on the planning process, the livelihood impact from the resettlement and the role of the funding sources [11,13-17]. Although these studies show that the resettlement planning process and the Resettlement Planning Framework adhered to good governance principles, little is known about how much of good governance principles were applied during the compulsory land acquisition and resettlement process $[14,17,18]$. The problems arising out of the implementation of well-formulated plans suggest a non-adherence to good governance in the implementation phase $[15,17]$.

Given the little experience that Ghana has when it comes to undertaking resettlement on customary lands, this paper aims to build and apply an assessment framework for monitoring of the implementation phase resettlement activities on customary lands on the basis of good governance based on the thesis by the first author [19]. This framework is then applied to the Bui Dam Project. To reach this aim, the research questions that will be answered are: What is the relationship between good governance and resettlement? How can good governance be assessed in the implementation of a resettlement project in the absence of overarching guidelines? Did the implantation of the Bui Dam resettlement meet the principles of good governance?

In the following section, governance and resettlement from compulsory land acquisition are connected to build an assessment framework for assessing good governance in the implementation of resettlement. The study area discussing the resettlement process precedes the research methodology. Results on the assessment of good governance in the Bui Dam Project are then presented, followed by discussions and conclusions.

\section{Governance, Customary Lands and Resettlement from Compulsory Land Acquisition: The Nexus}

This section seeks to provide a background to governance, customary lands and resettlement. A framework for the monitoring of resettlement activities based on the principles of good governance is then built.

\subsection{Governance and Good Governance Principles}

Governance is a broad concept, with many views relating to its make-up. This study will define governance as how the society is managed through formal institutions and informal arrangements in order to reconcile the interests, obligations and priorities of citizens, interest groups and public officials [20-22]. Governance involves a set of actors, the "governors"1 and the "governed" that represent an all-inclusive and accountable process of decision-making as opposed to the conventional assumption focused on the government as the single individual institution in governance. The quality of governance is generally assessed by setting the mandate against actions in terms of the principles of transparency, public participation, equity and rule of law and accountability [23,24]. Good governance especially in terms of land administration is aimed at protecting the property rights of individuals and enterprises, as well as those of the state through the introduction of the good governance principles. These principles are however not an end in themselves, but a means to an end. Good governance is present where the identified principles are considered in the manner, processes and tools for decision-making, planning and implementation of projects [24,25].

\footnotetext{
This includes the government, large private interests and the institutions.

This includes the citizens, the civil society and their institutions.
} 


\subsection{Customary Lands}

Customary lands is a multi-dimensional term that is used by different authors with different terms such as commons, communal lands, traditional lands and indigenous lands [26-30]. In an attempt at a universal definition, several studies have tried to streamline the various definitions from different contexts and regions. In this study, customary lands will be defined with three elements; first, land that is held on the basis of indigenous tenure rules that have evolved locally; secondly, the land holding is based on group and individual rights; and thirdly, the rights, responsibilities and restrictions over these lands have arisen as a result of accepted practices based on the customs and traditions of the group $[27,30,31]$.

It is estimated that about $78 \%$ of land in Ghana is held in customary ownership while $20 \%$ is held by the state as public lands, and the remaining $2 \%$ is held in joint ownership by the state and the customary ownership [32,33]. Lands in Ghana are therefore held off the stool, skin, clan, family or state. Ollennu [34] identifies the two classes of people who access customary lands as the indigenous members/groups and the non-indigenous members/groups of a land-owning group. The indigenous members/groups have a lifelong right of use and access to the land by virtue of their membership of the land-owning group for their own use (Customary Freehold) [19,35,36]. The non-indigenous members, such as settlers and migrants in the area, may also be allocated a parcel of land subject to the land being vacant and the beneficiary's respect for the community's traditions and customs [37]. Though citizenship of a traditional area is conventionally based on the endeavors and the privileges of one's ancestors, and the resulting uterine lineage, Boni [38] describes situations in the cocoa growing regions of the country where settlers claim membership of the indigenous land-owning group as citizens (as opposed to being "strangers") due to their long stay in the area, as well as their participation and contribution to the group. Berry [39] however indicates that this citizenship described here, unlike a state citizenship, which is well-defined, is not subject to any formal laws, but to the dynamic customary rules, and is therefore subject to several interpretations.

The main method of public land acquisition in Ghana is through compulsory land acquisition $[37,40]$. The 1992 constitution of Ghana defines public or state land as "any land vested in the government in trust for, and on behalf of the people of Ghana for the public service of Ghana, and any other land acquired in public interest for the purposes of the Government of Ghana" [41].

\subsection{Resettlement from Compulsory Land Acquisition}

Resettlement is the relocation of a group of people from their original settlement to another settlement. Asiama [19] identifies four forms of resettlement as voluntary and planned, voluntary and spontaneous, involuntary and spontaneous and involuntary and planned resettlements. These four forms of resettlement result from different activities. The resettlement resulting from a compulsory land acquisition is the involuntary and planned resettlement. This is defined as the physical transfer of individuals or groups from their usual residence to another location by an external body with the provision of housing, basic services and infrastructure, livelihood opportunities and security of tenure to the displaced persons in the new location [19,42]. Cernea [43] identifies the parties in a resettlement as the acquiring body, the resettled population and the host population. It is uncommon for the acquiring authority to find bare land without owners or inhabitants to resettle the displaced population. The host population is the community within or near the area to which the affected population are to be relocated, where they will have to share land, social services and other natural resources [44]. The host population is usually omitted during the planning of the resettlement; however, this brings about difficult problems during the implementation. This is because although the host community may react well to the arrival of the resettlers, the resulting increase in population, along with the increase in the demand for water, food and social services may render them inadequate. Conflicts may also arise where the acquiring authority only caters for the resettlers and neglects the host population [45]. Although the thorough integration of resettlers and the host community is a 
gradual process, Cernea [43] recommends the formulation of policies to speed it up in order to rebuild the severed social connections and have a viable community.

Financial compensation, the second form of compensation for compulsory land acquisition, is the provision made for persons whose properties have been compulsorily taken to reimburse them for the property loss, as well as the associated losses. Alias and Daud [46] indicate the goal of compensation as an attempt to reinstate the affected person to his/her former station prior to the acquisition if not better. Financial compensation is the payment of the monetary equivalent of the property lost, as well as the other associated losses, to the affected persons [47]. Financial compensation and resettlement is combined in some cases as the form of compensation [9].

\subsection{Monitoring Resettlement from Compulsory Land Acquisition: A Good Governance: Assessment Framework}

The unacceptable adverse socio-economic impacts of large dams have driven multi-lateral donor groups to adopt sophisticated sets of policies, operational procedures and guidelines to guide the resettlement process. The World Bank, having a lot of experience in this area, has taken the lead to formulate the Operational Policy/Bank Policy (OP/BP) 4.12 with the objective of aiding affected persons' efforts to at least restore their livelihoods, if not improve them, to the standards prior to the to the resettlement [44]. An important requirement identified in these policies for every step in the resettlement process is the application of the principle of the Free, Prior and Informed Consent (FPIC) to level the playing field for the three players: the state and its agencies, the market and the civil society [48,49]. The FPIC advocated goes in tandem with the recent trend that shifts focus from a centrally-planned and technology-driven decision-making approach to a more participatory and integrated approach to development projects. This provides a strong basis for good governance in decision-making, leading to the redistribution of the roles and the responsibilities among the governance players [50].

The significance of good governance in resettlement can be viewed from its essence with respect to land administration in general [19]. Tenure security and land access, being basic elements of economic growth and social development, have the restoration of the livelihoods of the affected persons dependent upon them. In order for this to be fulfilled, there is the need for a transparent, participatory, equitable and a corruption-free accountable system that will safeguard the cultural heritage, minority interests and the livelihood [51]. Good governance in public administration is aimed at protecting the rights of individuals, organizations, as well as the state through the introduction of certain principles in the management of public activities, paving the way for a common ground for negotiations and discussions amongst the actors and the stakeholders. These principles cover many areas; however, in this study, the four that are found to be broadly dealt with in the literature of land administration cover transparency, public participation and inclusiveness, equity and rule of law and accountability (other salient good governance principles such as effectiveness and efficiency and responsiveness are touched upon within these four principles, but not in detail) [19-21,52].

\subsubsection{Transparency}

Transparency in resettlement can be viewed as comprising two components: access to information and openness of the process $[25,53]$. The dissemination of and access to timely and relevant information to all affected persons and their representatives provides a solid platform for their participation in the decision-making and collaboration with the acquiring authority [44,54]. This aids in reducing the fears and misconceptions of the affected persons and builds their trust in the project. With the complicated nature of the resettlement process, information needs to be as simple as possible for the affected persons. For transparency to be maintained, studies have shown the need for a high level of accessibility to resettlement plans, together with the level of bureaucracy, and the complexity of the information provided. With regards to the openness of the process, the clarity and simplicity of the information provided is called into question. This involves the timely sharing of information regarding 
the timeline of the land acquisition and resettlement process, the determination of compensation, both the form and quantity, as well as the available sites for resettlement and their related information.

\subsubsection{Public Participation and Inclusiveness}

Public participation falls at the heart of the implementation of the FPIC principle encompassing the involvement of all relevant parties and the nature of the decision-making process [55-57]. The planning of resettlement is usually done in broad consultation with several stakeholders and actors ranging from the national level to the local level, who are directly or indirectly affected by the land acquisition and resettlement for the dam, with each one having their own benefits [20,58]. The three key actors in a resettlement that is in line with good governance principles are the state, the market and the civil society $[1,45]$. The state in this case is the government of the project country that usually initiates the project. The state may also encompass the authority that is acting for and on behalf of the government to undertake the project. The market is any other body, apart from the state, that is directly or indirectly affected by the land acquisition and the resettlement, as well as their agents and representatives. The market may include the affected community, the host community, as well as other users of the natural resources involved. The civil society describes the groups that operate outside the scope of the state and the market and are not financially motivated by either group, in the interest of the citizens, especially the minority and vulnerable groups. They usually play the role of the watchdogs in the resettlement process. Benefits of public participation for each of these groups differ from each other. For the market, public participation allows for their insight in the process to be utilized so their needs can be adequately met. In the same vein, on the part of the state, it helps for the peculiar social, cultural and economic issues that are specific to the area to be identified and dealt with in the appropriate manner. This will help to reduce the occurrences of inaccurate assumptions about the needs and preferences of the affected persons. Customary areas are especially vulnerable when assumptions area made about their practices. This is due to the dynamic nature of the customary system, rendering every area unique in its norms and customs. Furthermore, the need for public participation determines how the outcome of the project affects not just the present generation, but also the generations yet to come. The nature of public participation takes different forms as already seen. The World Bank [44] therefore recommends in the World Bank Resettlement Policy Framework that the level of participation should not just be at the informing and consultation level of public participation in the planning and implementation, but it must reach the level of collaboration and partnership. This level of participation will enable the acquiring body to share the success or failure of the project with the affected persons. It will also reduce the costs that may be incurred later from supporting the affected persons as a result (dependency syndrome) [43]. Public participation requirements in resettlement encompass the manner through which the market is involved in the determination of the key parts of the land acquisition and the resettlement such as the type and assessment of compensation and the determination of the resettlement sites. With the several policies, laws and regulations covering the resettlement procedure, as well as the technical details that may not be familiar to the affected persons, an important aspect of public participation is the involvement of professionals who work for the affected persons.

\subsubsection{Equity and Rule of Law}

Equitable considerations in land acquisition and resettlement seek to hold the standard that all affected persons should have the same service considerations and treatment [24]. Equity and rule of law in resettlement here covers the fair and adequate compensation, tenure security, livelihood restoration, equal treatment of all parties involved and upholding of the rule of law. Beyond this, Curry [59] illustrates two perspectives of equity, being distributional and intergenerational equity. The former ensures that the needs of the minority and the vulnerable are not overlooked through a fair distribution of the resources. Intergenerational equity deals with the efficient and effective distribution of rights and resources with adequate consideration for the future generation. This similarly applies to the assessment of compensation. In expressing the importance of intergenerational equity consideration in customary 
lands, Ollennu [34] points out that " ... land belongs to many who are dead, few who are living, and countless yet unborn". The assessment of compensation is aimed at reinstating the affected party to his/her living standards prior to the land take, if not better. Compensation may be either monetary, resettlement or both. Experience in Ghana and other parts of Sub-Saharan Africa has shown that where the monetary form of compensation is used, the affected persons find it difficult to manage the sudden apparent monetary gain and fail to appropriately invest the money, leaving them destitute after a few years. The solution to this is the use of resettlement. The resettlement replaces everything that was taken at least at the minimum living standards, as well as other incentives and programs to make up for the "shock" caused by the sudden relocation and to help the affected persons back on their feet in terms of their livelihoods. Past resettlements such as dams on the Tana River in Kenya, Volta River Project in Ghana and the Kariba He Dam on the Zambezi in Zambia and Zimbabwe have caused impoverishment as their lands were simply replaced without considerations for their livelihoods $[4,60,61]$. The descendants of the project affected persons in these projects, which took place in the 1960s and 1970s respectively, are still facing problems related to housing, landlessness and economic hardships, relying on the acquiring authorities for their basic needs, sparking an endless cycle of dependency syndrome. Equity in resettlement entails the equal treatment of the affected persons regardless of their ethnicity, age, gender or standing in the community; assistance by professionals in the compensation assessment; as well as the respect for local and traditional norms and customs in the community.

The rule of law in resettlement requires the existence and adherence to the laws and regulations covering the process, as well as protection under those laws [62-64]. Rule of law therefore begins with a clear existing process for compulsory land acquisition and compensation outlined in the law, or a legally binding instrument [65]. This will allow the parties, especially the affected persons, to be more confident in the process.

\subsubsection{Accountability}

Effective accountability is one of the vital ways of combating corruption [51]. In assessing the quality of accountability in land administration, Graham et al. [66] suggests two things to know; first, whether there is a clear assignment of responsibilities to the people involved for the various functions to be performed and the responsibilities assigned to those involved are appropriate and are according to their skills; and secondly, the accountability arrangement itself. There are two forms of accountability arrangements: vertical accountability and horizontal accountability. The most common type is the vertical accountability, which is towards the governed, either directly or through the media and civic organizations. Horizontal accountability is the use of checks and balances at the level of the authority imposed upon it. An example of this is the existence of the legislative and judicial arms of government, the ombudsman and auditing agencies, to serve as checks on the executive arm of government. With respect to accountability in the land acquisition and resettlement process, some of the indicators that will show accountability are the clear assignment of responsibilities to the parties involved, the appropriateness of the responsibilities assigned and the existence of bodies to horizontally and vertically check the acquiring authority.

\subsubsection{The Assessment Framework}

Table 1 below presents the breakdown of good governance assessment framework for resettlement from compulsory land acquisition. The principles of good governance explained in the preceding sub-sections were broken down into thematic areas according to their relationship with resettlement. To build up the framework to be more specific and measurable, these thematic areas are further broken down into indicators which will be assessed towards the identified good governance principles. A good governance score can be assessed as a percentage of the positive result of the indicator $(\mathrm{Y})$ to the number of the indicators to provide a basis for comparison for other assessments. The function for the good governance score is:

$$
\mathrm{Y}=\mathrm{Y} /(\mathrm{Y}+\mathrm{N}) \times 100
$$


Table 1. Breakdown of good governance assessment framework for resettlement.

\begin{tabular}{|c|c|c|}
\hline Principle & Thematic Area & Indicator \\
\hline Transparency & Access to Information & $\begin{array}{l}\text { - Utilization of appropriate media in information provision. } \\
\text { - } \quad \text { Low level of complexity and bureaucracy in information provision. } \\
\text { - } \quad \text { Free access to information concerning the compulsory land } \\
\text { acquisition and resettlement. }\end{array}$ \\
\hline $\begin{array}{l}\text { Public Participation } \\
\text { and Inclusiveness }\end{array}$ & Decision-making Process & $\begin{array}{l}\text { - Possibility of the lodging complaints/making suggestions. } \\
\text { - } \quad \text { Abiture of response to the people's complaints/suggestions. } \\
\text { - } \quad \text { Explore other options of land acquisition apart from compulsory } \\
\text { land acquisition. } \\
\text { Involvement of community members in resettlement } \\
\text { allocation process. }\end{array}$ \\
\hline $\begin{array}{l}\text { Equity and Rule } \\
\text { of Law }\end{array}$ & $\begin{array}{l}\text { Livelihood and Equal } \\
\text { Treatment of Parties and } \\
\text { Rule of Law }\end{array}$ & $\begin{array}{l}\text { - } \quad \text { Formulation of and adherence to plans for livelihood rehabilitation. } \\
\text { - } \quad \text { Settlers are treated the same as indigenes. } \\
\text { - } \quad \text { The existence of laws and regulations governing the process. } \\
\text { - }\end{array}$ \\
\hline \multirow[t]{2}{*}{ Accountability } & $\begin{array}{l}\text { Assignment of } \\
\text { Responsibilities }\end{array}$ & $\begin{array}{l}\text { - } \quad \text { Clear assignment of responsibilities. } \\
\text { - } \quad \text { Appropriateness of the responsibility assignment. } \\
\text { - } \quad \text { Manner of selecting representatives. }\end{array}$ \\
\hline & Accountability Arrangement & $\begin{array}{l}\text { - Existence of body to horizontally and vertically check the authority. } \\
\text { - Justification of the decisions of the acquiring authorities. } \\
\text { - } \quad \text { fffectiveness of civil society and the media in mobilizing demand } \\
\text { - Sanctions for unaccountability. }\end{array}$ \\
\hline
\end{tabular}

\section{Study Area}

The area under study is the Bui Resettlement Township B. The township covers an area of one square kilometer, with a population of 654 forming 124 households. The township was created in 2011 to resettle the second of the two groups affected by the Bui Dam Project. The first group was resettled in the Township A in 2007 when they were affected by the dam construction. The township B inhabitants were affected by the inundation of the area by the reservoir created by the dam (Figure 1). 


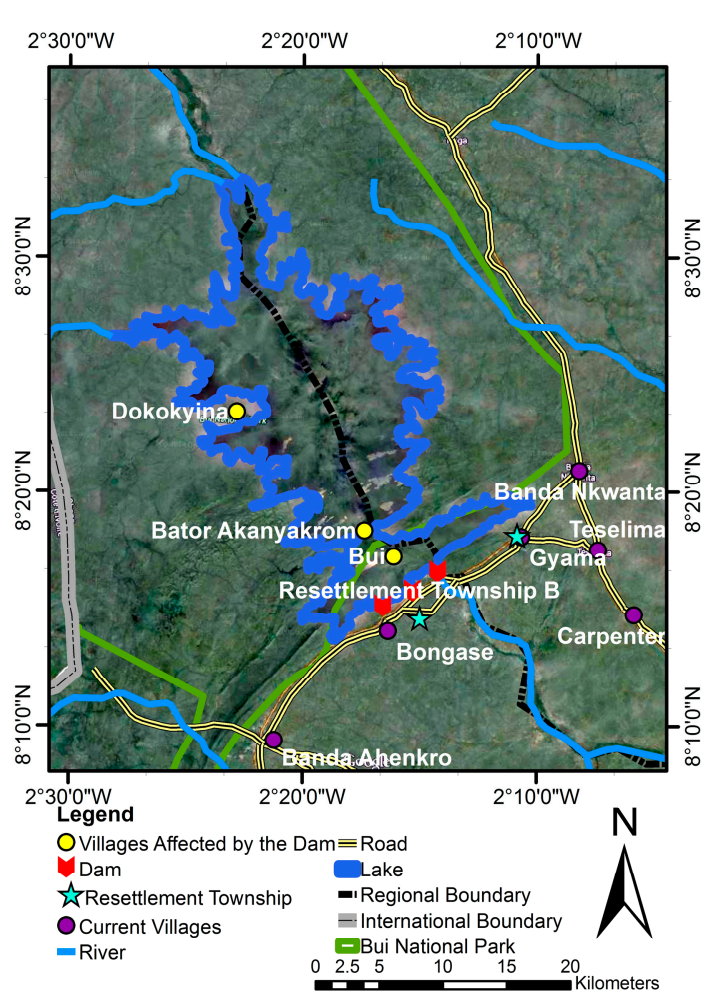

(a)

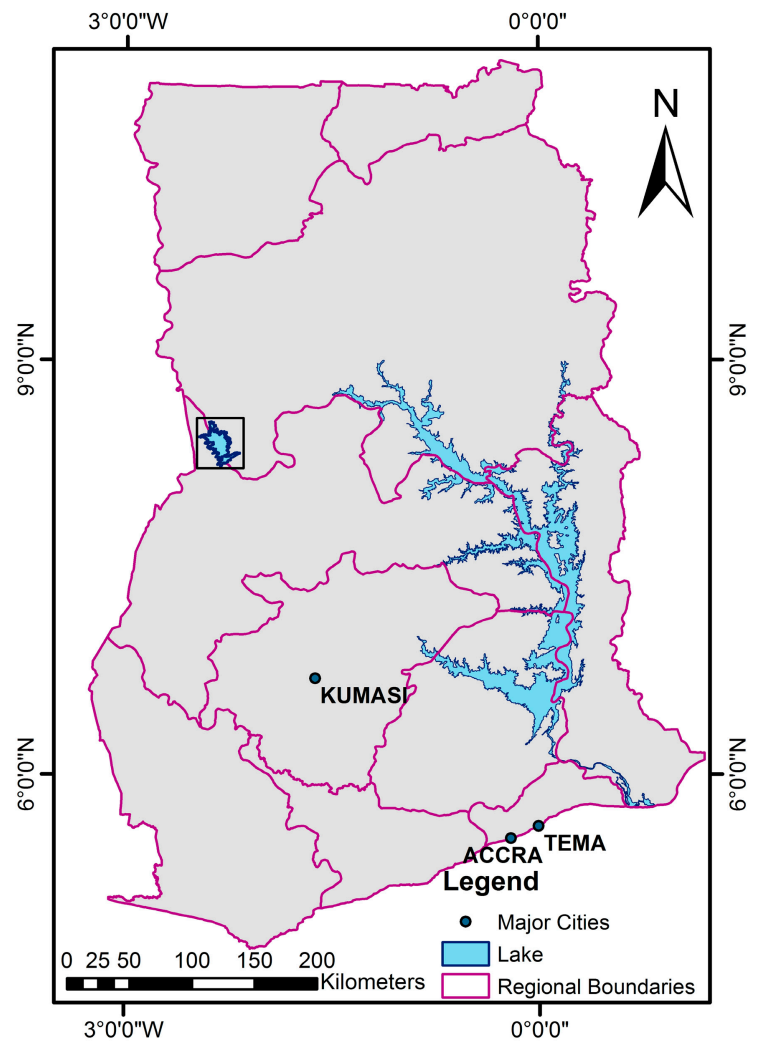

(b)

Figure 1. (a) Map showing the Bui Dam, the dam catchment area and the resettlement townships; (b) map of Ghana showing the location of the Bui Dam.

The Resettlement Township B is made up of three villages, the Bui Village, Bator and Dokokyina. The lands in the study area are held in customary land tenure. Bui and Dokokyina are predominantly natives of the Mo and Banda tribes, who are the indigenes of the area. The Dokokyina village was founded over 200 years ago, but the time of the founding of Bui is not clear. The Bator village is comprised of natives of the Ewe tribe who migrated from Tefle in the Volta Region of Ghana to the area to take up fishing in 1927. The villages are each administered by a chief who reports to the paramount chief of the Banda traditional area (Figure 2). They also have seats on the traditional council of the traditional area.

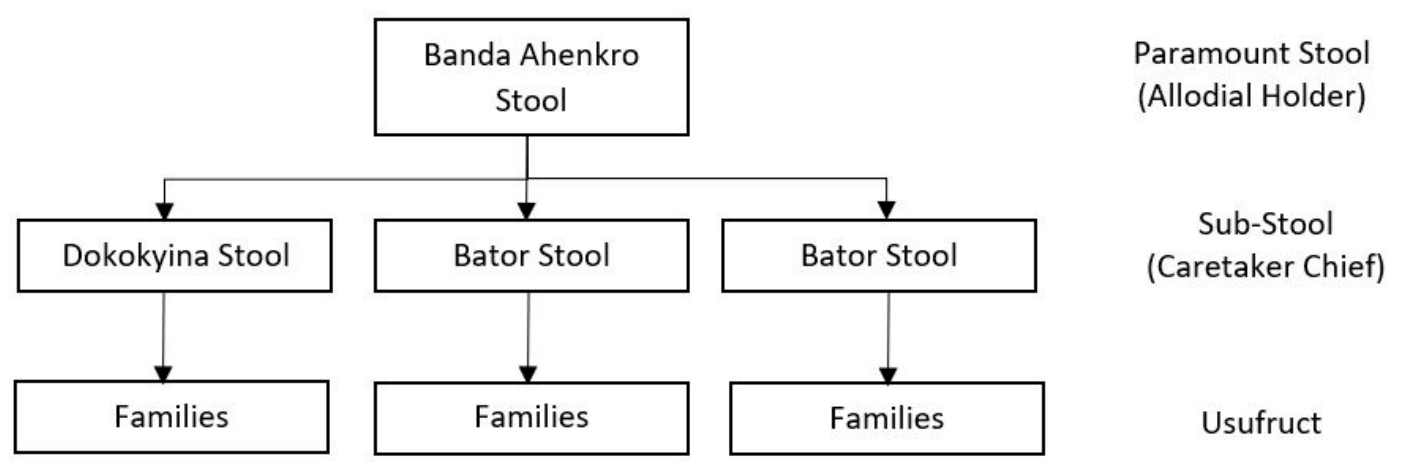

Figure 2. Chieftaincy and land tenure hierarchy in the area (author's construct). 


\section{Research Design and Methodology}

The aim of this study is to build and apply an assessment framework for monitoring resettlement activities from dam construction in customary lands based on good governance. A case study approach is used. Yin [67] recognizes the case study research approach as the most appropriate strategy where the research questions are more explanatory, with the research being based on an existing issue that have behavioral situations in the research environment ensuing within the real world context and beyond our control. The nature of compulsory land acquisition and resettlement coupled with the differing and sometimes unstable environment, as well as the accompanying social, economic, and cultural issues make the case study approach the most appropriate for this study. To be able to get a closer look at the phenomenon to get a deeper insight and broader exposure to it, the single case study approach is used in this study. A mix of quantitative and the qualitative methods is used.

The data collected comprised primary and secondary data. The primary data collection tools used were focus group discussions and structured and semi-structured interviews. The secondary data collected included the statutes, regulations, the Resettlement Planning Framework (RPF) and the claims made during the interviews. Semi-structured interviews, with opened-ended questions, were conducted for the Bui Power Authority and the Volta River Authority, the Lands Commission and the District Assembly (the Assembly member and the Unit Committee of area). The semi-structured interviews were used because of the depth of the information needed and the involvement of those respondents in the Resettlement Project. Structured interviews, with closed-ended questions, were conducted with a sample size of 38 households though the formula used below, reaching a sample size of 32. In the selection of the sample size for this study, the Alain Bouchard sampling formula is used as shown below;

$$
\text { Sample Size }(\mathrm{n})=\frac{(\mathrm{Z} \alpha / 2) 2 \times \mathrm{p}(1-\mathrm{p}) \times \mathrm{N}}{[(\mathrm{E} 2) \times \mathrm{N}]+[(\mathrm{Z} \alpha / 2) 2 \times \mathrm{p}(1-\mathrm{p})]}
$$

where:

$\mathrm{N}=$ population size (124 for this study)

$\mathrm{p}=$ the estimated frequency for the sample size $\mathrm{n}$; that is proportion of success ( $50 \%$ in this study)

$\mathrm{E}=$ tolerable error (15\% in this study)

$\mathrm{Z} \alpha / 2$ = value given for the confidence interval according to the precision desired (1.96 for this study).

$$
\text { Sample Size }(\mathrm{n})=\frac{1.96^{2} \times 0.5^{2} \times 124}{\left[\left(0.15^{2}\right) \times 124\right]+\left[1.96^{2} \times 0.5^{2}\right]}=32
$$

To make sure that both indigenes and settlers were interviewed, 19 of the respondents came from the area inhabited by indigenes, and the other 19 came from the settlers' area. A satellite image of the area was then obtained and used to identify the houses through which the selection of the households was made through systematic random sampling. The heads of the household were the main points of contact; however, where possible, other members of the family joined in. Although structured questionnaires with closed-ended questions were used, the respondents were given a chance to air their views, where they were willing to give reasons for or explain their responses further. These views were recorded on the questionnaires to be used in the analysis. The respondents were seen to be key in the study because they were directly involved in the planning and implementation of the process. Table 2 shows a profile of respondents representing the households.

Focus group discussions (FGD) were also conducted with key members of the community including the chiefs' elders, the leadership of the youth and the unit committee of the area. The number of participants ranged from four to seven depending on the number of people available at the time. The participants were also purposively selected and, in the case of the elders, with the help of the royal family heads of each village. The focus group discussion covered the salient issues regarding the compulsory land acquisition, which could not be discussed during the household interviews due to their 
brief nature. The focus group discussion was also used to validate the responses from the interviews with the households. For details of the questionnaires used, please refer to the Supplementary Material.

Table 2. Overview of the respondents of the household survey (total number of respondents $(\mathrm{n})=38)$.

\begin{tabular}{cccc}
\hline & Demographic Criteria & Number of Respondents & Percentage of Respondents \\
\hline \multirow{2}{*}{ Ethnicity } & Indigene (Banda and Mo) & 19 & $50 \%$ \\
& Settler (Ewe) & 19 & $50 \%$ \\
\hline \multirow{2}{*}{ Gender } & Male & 23 & 60 \\
& Female & 15 & 40 \\
\hline \multirow{3}{*}{ Educational Level } & Cannot Read, or Understand English & 23 & $60 \%$ \\
& Can Understand and Read English & 1 & $3 \%$ \\
& Primary & 3 & $8 \%$ \\
& Junior Secondary & 8 & $21 \%$ \\
& Senior Secondary/Technical/Vocational & 1 & $3 \%$ \\
& Tertiary & 2 & $5 \%$ \\
\end{tabular}

\section{Good Governance in the Implementation of the Bui Hydroelectric Dam Resettlement}

This section presents the results of good governance in the Bui Dam resettlement. The results are structured according to the relevant principles and thematic areas of good governance that are related to this work as explained in Section 2. It was generally found that there was high transparency in the resettlement and low transparency in the compulsory land acquisition process, low public participation and inclusiveness, inequality low level of the rule of law and a low level of accountability. The result of the assessment of the specific indicators is provided in Appendix A Table A1. The overall good governance score in the implementation of the Bui Hydroelectric Dam Resettlement was 27\%.

\subsection{High Transparency in Resettlement, Low Transparency in Compulsory Land Acquisition}

It was generally found that the involvement of two bodies handling the compulsory land acquisition and resettlement respectively resulted in differing levels of transparency, as the resettlement process, handled by the Bui Power Authority, was found to be very transparent, whereas the Lands Commission, which handled the compulsory land acquisition, was not as transparent.

\subsubsection{Access to Information}

To provide a strong link between the acquiring authority and the resettled community, the Bui Dam Project (BDP) strived to improve the information provision and access methods that were used in previous resettlement projects in Ghana, as well as others in developing countries (Bui Power Authority (BPA) Official). The BPA insinuated that the best practices for information provision were much adhered to. This sentiment was shared by the village elders and majority of the households, $84 \%$ of whom felt that the key method used in the provision of information helped them to at least understand what was going on. The media for communicating with the affected persons had a major effect on the response of their response and their ability to understand. It was seen that although the clarity related to the household surveys and public announcement was very high, this was not the same with the information provided through television and radio (12\%), as a majority of the population did not own either of these media $(70 \%)$, or did not understand the information put through (18\%) (Figure 3). This stands to reason as the information provided was mostly in English, to an audience that did not understand English. This notwithstanding, the affected persons were generally satisfied with the manner of information provision by the BPA.

On the other hand, access to information looks at how information is sought by the affected persons. Taking advantage of modern technology, the BPA used the cell phone as the prime medium of information access, primarily through a high-ranking BPA official. This was done to cut out the bureaucracy involved in the setting up of an information office in the various communities. This was however not a success initially as mobile phone coverage in the area was very low, with few people 
owning them. Therefore, they had no option but to walk at least seven kilometers to the resettlement office at the dam site when they needed information (Figure 1). The use of the mobile phones was also augmented by frequent visits of the resettlement officials to the affected communities. However, despite how seemingly effective this approach was, the community members, especially the youth, complained that although they knew they could go to the BPA officials directly, traditions and customs of the area required that the chief and elders be informed of the request before they will give permission for the community member to go the BPA official. This thus added another layer to the bureaucracy the BPA attempted to reduce.

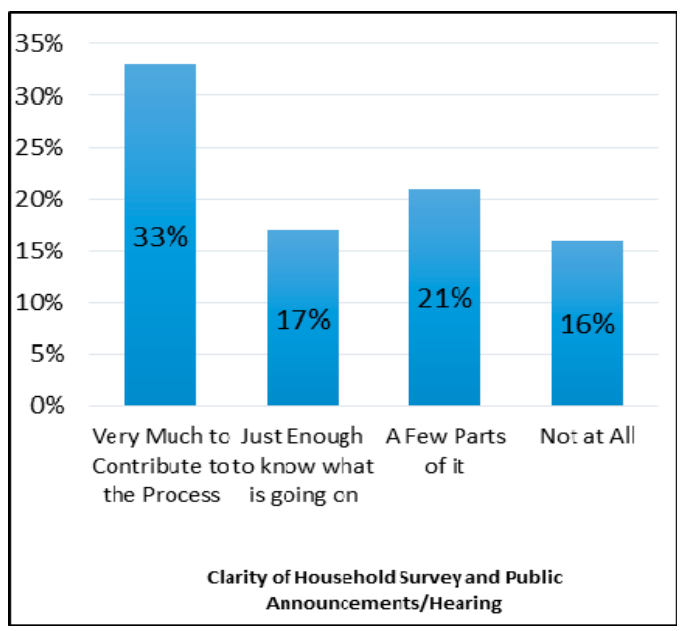

(a)

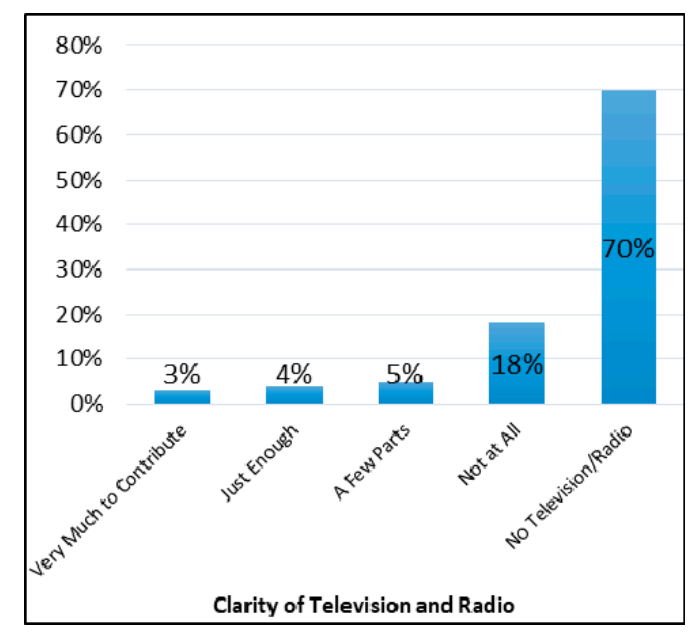

(b)

Figure 3. How clear was the information through these media? (a) Household survey/public announcement/hearing; $(\mathbf{b})$ television/radio $(n=38)$.

\subsubsection{Openness of the Process}

The openness of the process was determined by unpacking the land acquisition and resettlement process and assessing the understanding of the affected persons for each aspect. The affected persons showed that they were given adequate explanation regarding the land acquisition and resettlement process. However, looking at the individual aspects (Figure 4), it is seen that more people understood the aspects related to the resettlement processes (timetable and resettlement plans) than those in relation to land acquisition (compensation assessment).

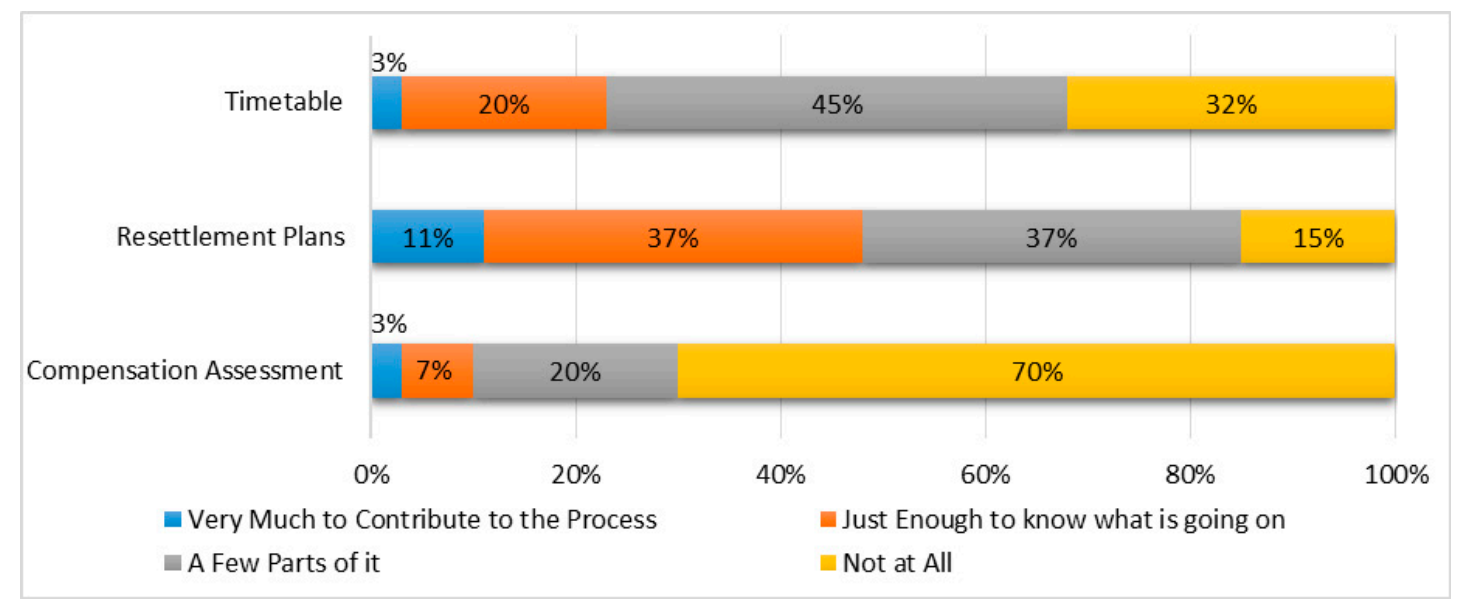

Figure 4. How clear were the explanations of these aspects of the compulsory land acquisition and resettlement process? $(n=38)$. 
The crop value rates and the payment schedule for compensation were not made available to the resettled persons in the process of crop valuation. This was because the lands commission (the valuation authority) insisted that the procedure for valuation and the rates used comprised confidential information, which could not be divulged. The resettlement process was however more open, with the resettled persons knowing exactly what the process entailed, as well as the timelines for each activity so they could adequately prepare. The openness of the process therefore differed depending on the body that was handling the process. The resettlement handled by the BPA was more open, compared to the compensation assessment handled by the Lands Commission.

\subsection{Low Public Participation}

Though it was found that the local people and their representatives were involved in the process, public participation was generally found to be low in the project, as there was a low involvement of the local people in the processes, their complaints received no responses and the local people had no say in the resettlement plans drawn up by the acquiring authority.

\subsubsection{Involvement of Actors}

Participation of the key actors in the resettlement process was mostly dependent on their level of expertise. The bodies that were involved in the resettlement planning from a governance perspective were for the State: the acquiring authority (the Bui Power Authority-BPA), the valuation authority (the Lands Commission), the Regulatory Body (Environmental Protection Agency-EPA) and the Collaborating Bodies (the Town and Country Planning Authority, the Ghana Health Service, the District Assembly and the Ghana Education Service). For the market, there was only one key actor, the resettled community, as there were no communities who were close enough to be designated a host community according to the characteristics set out by Cernea [43]. The key civil society group that was involved in the resettlement planning was the Ghana Dams Dialogue (GDD). However, the involvement of the market and the civil society groups in the resettlement implementation was minimal, as the acquiring authority, valuation authority, regulatory authority and the collaborating played larger roles due to their expertise in this area. The resettlement community was mostly represented by their leaders who were the Traditional Authorities, the Youth Leadership Committee and the Unit Committee of the District Assembly. However, the degree of involvement of these actors was largely dictated by the customary rules of the area. The Traditional Authority, in their role as the gatekeepers for the community, require that they know and control all information coming into and going out of the community. They were always the point of call for the BPA when the community needed to be engaged. The Youth Leadership Committee's involvement was seen as minimal for two reasons. First is that they did not have a direct line to the BPA, and secondly, since they were mostly farmers and fishermen, they were usually not available for the frequent community engagement with the BPA. They were therefore compelled to rely on the Traditional Authorities for their concerns to be raised. The involvement of the Unit Committee was also minimal in the initial stages as it drew its mandate and authority from the District Assembly, which was reluctant to get involved (Focus Group Discussion with the Unit Committee). However, with the involvement of the civil society group, the District Assembly got more involved either as a party or as a witness to the negotiations. Although the acquiring authority's aim to reduce bureaucracy led it to try to engage the community members directly, this was frowned upon by the Traditional Authorities, who saw it as a ploy to subvert their authority (FGD with Traditional Authority).

\subsubsection{The Decision-Making Process}

The decision-making process was much related to transparency as information received determined how effective the resettled persons would be in the decision-making. The basic tenets of an effective decision-making are for all parties involved to be given an equal chance to make suggestions, and lodge complaints, and for these to be taken into consideration by all parties involved. 
However, in the Bui Dam Resettlement, although suggestions and complaints were made and received by the BPA, it only amounted to a consultation, as admitted by the BPA officials. Ninety two percent of the community members agree that they were consulted in the decisions taken through the almost daily meetings with the acquiring authority. However, asked whether they saw their suggestions in the implementation, the number reduced to $39 \%$. One key decision was the choice of the resettlement site. According to the BPA official, the aim was to consolidate the three communities into one, to save resources. However, due to their vocational differences, the fishing community, Bator, sought to be resettled close to the river, in an area allocated to them by the Paramount Chief (Bator Elders). However, this was vetoed by the BPA, and the three communities were consolidated into one resettlement township far from the lake. However, the BPA official pointed out that the choice of the resettlement site was made by the community members themselves. With regards to the handling of the complaints, although a specially-planned comprehensive grievance process was planned that would see a community member appointed by the chiefs in the area as the Grievance and Liaison Officer, the lodging of complaints was done the same way as the acquisition of information: through a phone to a BPA Official. However, due to the customary arrangements, as with transparency, the Traditional Authorities as gatekeepers made the process lengthy. Therefore, out of the $68 \%$ of the community members who knew how to lodge complaints, $32 \%$ successfully lodged a complaint, with $8 \%$ seeing some action being taken on the complaint. The decision-making process is in relation to aspects of the resettlement that require technical expertise such as the design of the houses, the valuation of assets and the provision of legal advice were all handled by the authority without the community being educated and given the opportunity to hire their own team of professionals.

\subsection{Inequity and Low Level of Rule of Law}

The results showed a low level of equity and rule of law. This was characterized by inadequate, delayed and low compensation, a low perception of tenure security (though legal tenure security was found to be high), the absence of a comprehensive legally-binding livelihood enhancement and resettlement plan and the unequal treatment of the settlers and indigenes.

\subsubsection{Inadequate Compensation and Tenure Security}

The compensation assessment was undertaken solely by the Lands Commission (a government agency) with no involvement of land valuers and lawyers representing the affected persons. The agreed compensation was resettlement for the residential land and monetary compensation for the farms. The Elders of the communities and the Youth Leadership Committee both corroborate that the community suggested the engagement of their own professionals to aid them in understanding the process and to negotiate for the crop values, but this suggestion was discouraged by the Lands Commission. The Lands Commission's reason for this stance is that it is the only mandated body to undertake valuation for compensation purposes under the State Lands Act, without any opportunity for compensation negotiations (Lands Commission officials and Focus Group Discussion with the Elders). The crop values were not revealed to the farmers or their representatives as this was described as privileged information by the Lands Commission. The payment of compensation for the allodial interest was made to the paramount chief of the area as he holds the allodial interest in trust for the people. This was then supposed to be distributed to the village chiefs and then the family heads as the holders of the customary freehold. However, this compensation never trickled down to the family heads as it was decided to be used for development works in the traditional area by the traditional council. Every member of the community was to be compensated for their assets. However, only $3 \%$ of the respondents received their compensation within six months of the land take; $76 \%$ received theirs after six months; and 21\% never received compensation. However, since the community members were not privy to the rate used for the valuation, it is not clear whether interest was paid with the late compensation. This affected the tenure security as the affected persons reported that although they had been given new land for residence and agriculture, they still did not feel tenure secure due to what 
they described as a fear that their lands would be taken from them again. Hence, whilst the affected persons enjoyed legal tenure security, they did not feel tenure secure.

\subsubsection{Lost Livelihoods, Unequal Treatment of Affected Persons and Low Rule of Law}

Ghana's constitution requires resettlements to be done with due regards to the economic well-being of the affected persons, which was the aim of the BPA (BPA Official). To this end, the Resettlement Planning Framework made provision for the establishment of a Livelihood Enhancement Program (LEP) to create opportunities for the affected persons to restore and enhance their livelihoods as a form of benefit-sharing from the dam. This was to cover the key livelihood activities in the area: farming, fishing and trade/business [68]. The re-establishment of farms was more successful as there was a marginal reduction in the number of people who left farming: $95 \%$ of the respondents to $78 \%$ (Household Survey, 2014). This is despite the monthly allowance of Gh $₫ 50$ (EUR 30) given to the farmers as they re-established their farms, without any agricultural extension services (the official minimum monthly wage at the time was Ghф71.55 (EUR 47.70) [69]).

The two main occupations in the area were fishing and farming (Table 2). Farming was successfully re-established with the farmers receiving equivalent sizes of farmlands. However, fishing was not re-established as farming was. The previous fishing community, Bator, was some $150 \mathrm{~m}$ away from the Black Volta. From their current site, the community is 11 kilometers to the nearest fishing grounds. With almost no community member having a means of transportation, they have to walk. They have therefore had to give up fishing as the walk is especially tedious for the older community members. Summarizing their foresight to this situation, an elder of the Bator community lamented "We told the BPA that we are a fishing community. We therefore identified an area within the traditional area's boundary close to the river and rich in fish. We made this known to the paramount chief, who gave his consent and blessings, and we informed the BPA about it. But we were still sent far from the river". Furthermore, the community had together built a fishing pond in their old settlement to support their fishing during the lean season. However, this fish pond was never rebuilt as planned, but the BPA rather suggested financial compensation, which the affected persons rejected.

The livelihood plans were never implemented for the fishermen. With no alternate fishing grounds to turn to, the fishing in the resettlement community is almost dead, with the number of fishermen reducing from $21 \%$ of the population to $3 \%$ (Tables 3 and 4). This has also affected the trading activities in the area as they are closely aligned to fishing and farming (FGD with Unit Committee). Farmers have their wives selling the surplus food crops, and the wives of the fishermen sold the surplus fish. This meant that the slowdown in the fishing activities also had a significant impact on the fish mongering businesses (Table 4).

Table 3. Occupations of the affected persons prior to the resettlement (number of indigenes = 19; number of settlers $=19 ; \mathrm{n}=38$ ).

\begin{tabular}{ccccccc}
\hline \multicolumn{7}{c}{ Prior Primary Occupation } \\
\hline & Civil Service & Business & Crop Farming & Fishing & Retired & Unemployed \\
\hline Indigenes & 3 & 3 & 18 & 1 & 1 & 1 \\
\% of Indigenes & $16 \%$ & $16 \%$ & $95 \%$ & $5 \%$ & $5 \%$ & $5 \%$ \\
Settlers & 4 & 8 & 12 & 7 & 0 & 0 \\
$\%$ of Settlers & $21 \%$ & $42 \%$ & $63 \%$ & $37 \%$ & $0 \%$ & $0 \%$ \\
Total & 7 & 11 & 30 & 8 & 1 & 1 \\
$\%$ of Sample (n) & $18 \%$ & $29 \%$ & $79 \%$ & $21 \%$ & $3 \%$ & $3 \%$ \\
\hline
\end{tabular}


Table 4. Occupations of the affected persons after the resettlement (number of indigenes = 19; number of settlers $=19$ ).

\begin{tabular}{ccccccc}
\hline \multicolumn{7}{c}{ Current Primary Occupation } \\
\hline & Civil Service & Business & Crop Farming & Fishing & Retired & Unemployed \\
\hline Indigenes & 3 & 3 & 17 & 0 & 2 & 1 \\
\% of Indigenes & $16 \%$ & $16 \%$ & $90 \%$ & $0 \%$ & $11 \%$ & $5 \%$ \\
Settlers & 4 & 4 & 11 & 1 & 0 & 4 \\
$\%$ of Settlers & $21 \%$ & $21 \%$ & $58 \%$ & $5 \%$ & $0 \%$ & $21 \%$ \\
Total & 7 & 7 & 28 & 1 & 2 & 5 \\
$\%$ of Sample (n) & $18 \%$ & $18 \%$ & $74 \%$ & $3 \%$ & $5 \%$ & $13 \%$ \\
\hline
\end{tabular}

This apparent difference between the treatment of the indigenes and settlers was not clear to the expropriated; however, when asked whether they saw the implementation of their views, the results showed that the ratio of the indigenes who saw their views being implemented to the settlers who saw same was two to one (Figure 5). This shows a possible preferential treatment towards the indigenes at the expense of the settlers. This was also reflected on the changes in the occupations of the affected persons with respect to indigenes and settlers (Table 3). It is seen that farming marginally reduced among the indigenes, whereas fishing significantly reduced among the settlers with unemployment rising to $21 \%$. The businesses of the settlers were also seen to suffer a significant reduction.

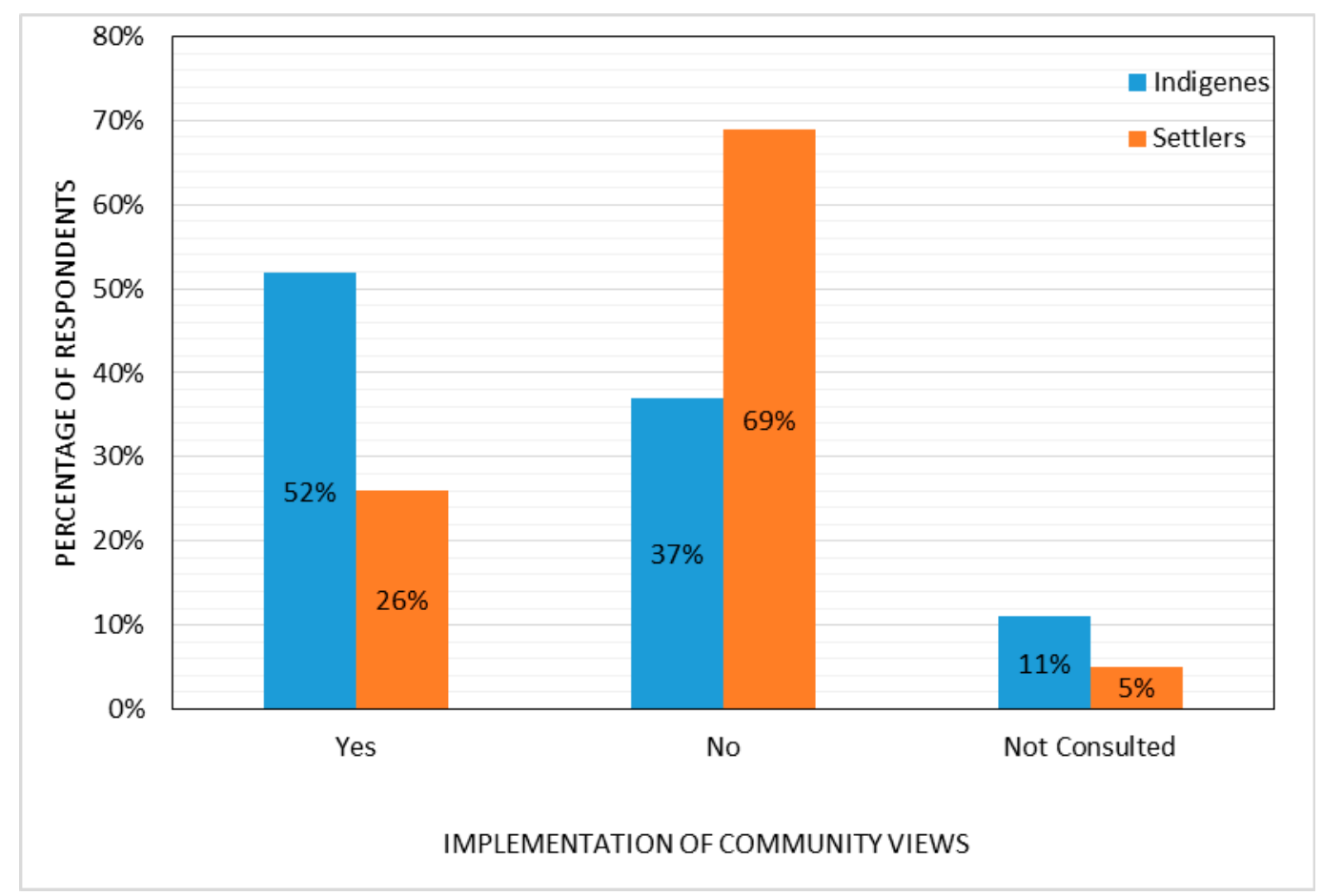

Figure 5. Implementation of community views according to ethnicity (number of indigenes = 19; number of settlers $=19$ ).

With respect to the rule of law, Ghana's inexperience with resettlement leaves its 1992 Constitution as the only legal provision guiding resettlement. It requires the affected persons to be resettled, taking their economic well-being, social and cultural values into consideration. Since this provided no specific guidelines for the acquiring authority, the acquiring authority formulated the Resettlement Planning Framework (RPF) based on the World Bank's OP 4.18. However, as these provisions were not legally binding on the BPA, it was not required to follow them. 


\subsection{Low Level of Accountability}

In terms of accountability, though there was a clear assignment of responsibilities to the appropriate bodies, there were no working structures put in place to effectively hold these bodies accountable for their actions (or inactions).

\subsubsection{Assignment of Responsibilities}

With the authority's core mandate being the development of the hydroelectric project, the results showed that it rightly assigned activities that were outside its scope to the appropriate bodies. These included the Ghana Education Service, the Ghana Health Service and the District Assembly handling education, health and sanitation, respectively. The Town and Country Planning Department was also at hand to aid with the development of the resettlement site. However, the role of these government bodies was purely advisory until the resettlement site was completed and handed over to them ${ }^{3}$.

\subsubsection{Accountability Arrangements}

The BPA in its activities was not answerable to the affected persons, although the Environmental Protection Agency (EPA) and the Water Resource Commission (WRC) provided some form of government oversight ${ }^{4}$. However, these oversight activities did not cover the resettlement activities. Therefore, to ensure accountability, the Resettlement Planning Framework made provision for internal monitoring and external evaluation mechanisms that comprises the representatives of the affected persons, an NGO and the appropriate governmental bodies. Three evaluations were to take place within the first six months of the resettlement, after 18 months and after 36 months to assess to conditions of the affected persons [68]. However, these never took place, although the Ghana Dams Dialogue played a mediating role between the affected persons and the BPA. In terms of the internal monitoring, the community met with the BPA three times within the first six months after they were moved, and their links with the BPA were severed. Regarding justifying their decisions, as the community members did not write down the agreements on the laid down plans, the BPA usually went back on the agreed plans ${ }^{5}$. However, the involvement of the NGOs and the media aided with raising the level of accountability especially in relation to the livelihood aspects of the resettlement ${ }^{6}$.

\section{Discussion}

This section discusses the results from the previous section in terms of the relevant good governance principles identified in Section 2.

\subsection{Transparency: Access to Information and Openness of the Process}

Access to information is the gateway to participation of the affected persons in a compulsory land acquisition and resettlement process. The tools used in the provision of information in the Bui Dam resettlement process-television, radio, public announcements-are all theoretically effective tools according to Adu-Gyamfi and UN-Habitat [32,70]. However, rom the results from the interviews, this was not effective in the Bui Dam resettlement project, as majority of the people did not have access to televisions and radio. The few who owned these media did not understand the information being put across. The public announcements and household surveys were rather more effective. This is due to the close-knit nature of the communities involved. The Resettlement Planning Framework (RPF) further suggested the establishment of information centers for each community to be manned by the locals. This was done to build the trust of the local people in the process [43,71]. The project

\footnotetext{
Interview with the Resettlement Officer.

Interview with the Resettlement Officer.

Focus group discussion with Unit Committee Members.

Interview with the Resettlement Officer.
} 
implementation rather took a different approach, establishing the Community and Relations and Resettlement Office at the dam site, being operated by a Resettlement Officer who was not a local. The use of mobile phones as a source of information reduced the bureaucracy on the part of the BPA, though this has not been covered by recent literature. The Resettlement office had a dedicated phone line to deal with the information requests from the community members. However, the stature of the chiefs as gatekeepers increased bureaucracy on the side of the local community [72].

The explanation and timely information on the compulsory acquisition process has not been part of past resettlements in Ghana [18,61]. However, the BPA and the Lands Commission sought to break this trend by explaining the entire process of resettlement and compulsory land acquisition respectively to the local people. However, the understanding of the local people of the two processes differed with the two bodies. Though the people understood the BPA's explanation of the resettlement plans and the timeline for resettlement, the Lands Commission's explanation of the compensation assessment and the payment schedule was not well understood by the community members. This is because in the law governing compulsory land acquisition in Ghana, there is no requirement for the process to be explained to the local people. This practice is confirmed by Anim-Odame [40], who indicates that the Lands Commission is more cooperative with professionals in the real estate industry than with the local people as these professionals are more versed with the technical aspects and procedures. This disparity shows that the BPA and the Lands Commission did not adhere to the OP 4.12 that requires the education of the project affected persons. This is a contrasts with a compulsory land acquisition in a Millennium Development Authority-funded project where the lands commission adhered to the information provision to the project affected persons in the OP 4.12 [40].

\subsection{Public Participation and Inclusiveness}

On the part of public participation, it was found that though the affected persons felt very much involved in the process, their participation was found to be subject to the traditional authorities who acted as gatekeepers to the community. This included the Unit Committee who worked through to the traditional authorities, a departure from the findings of Ubink and Quan [72] that the local government was always in direct confrontation with the traditional authorities. The frequency of the meetings between the affected persons and their representatives showed a close contact; however, as the BPA usually met with the traditional, there was less interaction between the affected persons and the BPA. However, the people felt that their views were adequately put forward by the traditional authorities, as found by Cernea [43] that the involvement of the traditional authorities expedites communication and cooperation because of the respect and trust for them. However, the youth of the community felt left out of the process because they felt that whilst their views and needs were not adequately communicated by the traditional authorities, they were also not allowed to be in direct contact with the BPA.

The low participation of affected persons in past resettlements has adversely affected the results of the resettlement causing a lack of trust between the two parties, and later over dependence on the acquiring authority [17,61]. The World Bank [44] recommends that for the Free, Prior and Informed Consent (FPIC) to exist, the involvement of the affected persons needs to reach at least the level of partnership/cooperative participation. The field results showed the views of the affected persons were sought albeit more often through their representatives than through a direct interaction. The opportunity to lodge complaints was also stifled by the gatekeeper status of the traditional authorities, putting the situation at odds with the findings of Juul and Lund [73] who found that community members' involvement in decision-making on customary lands is high. The BPA, however, saw that the people's views were considered; however, there were certain laws and regulations that restricted them from implementing the people's views. Therefore, the lack of a feedback system in the process resulted in a loss of confidence in the decision-making process as is demonstrated by Ewan and Smith $[74,75]$. 


\subsection{Equity and Rule of Law: Compensation, Livelihood Revival and Treatment of Affected Persons}

The compensation for the land taken in the Bui Dam project was paid to the traditional authorities who manage the allodial title. This was done in order not to upset the customary arrangements of the affected persons. According to the customary practice, the compensation should be paid to the holder of the allodial interest and then distributed to the holders of the lower title holders. However, this did not happen as with the practice of stool land revenue distribution [72]. In terms of the time for the payment of the compensation, the related literature and the OP 4.12 did not define an appropriate time for the payment of the compensation, as this is relative, depending on the area. However, an indication of the proper time for the payment of compensation in Ghana has been given by the Mines (Compensation and Resettlement) Regulations [76] as within three months. From the field study, it was found that the minimum payment for the compensation for most of the affected persons was six months. Though the bureaucracy related to the approval of compensation explains a part of the problem, Larbi et al. [7] is of the view that the detachment of the compensation payment from the compulsory land acquisition process by the State Lands Act [77] also contributes to the late payment.

An important way of maintaining intergenerational equity is the restoration of the livelihood of the affected persons after resettlement. Past studies have blamed the failure of livelihood restoration on inadequate resettlement plans [55,78]. Mettle's [17] assessment of the Livelihood Enhancement Program (LEP) showed a detailed program; however, this never took off. In lieu of this, money was provided to the affected persons to enable them to restart their lives, although the results show that this was not enough. Similar instances are reported by Kusiluka et al. and Syagga and Olima [6,78] for resettlements in Tanzania and Kenya, with the later recommending post-resettlement assistance and monitoring for a period of at least five years. Cernea [43] however warns that the provision of support after the end of the process should not be paternalistic in nature, but should rouse the commitment of the resettlers to self-sustainability and development through self-mobilization. There is therefore a fine line to be trod for a successful livelihood restoration. The Bui Dam Project however differed from this approach, and the affected persons were left on their own soon after the project was completed. The results from Township B covered in this research are however at odds with those of Township A where Naab et al. [14] find that there were few changes to the primary occupation, mostly because the community was settled close to the waterbody.

Though equal participation by all affected persons has been found to yield positive results in resettlement, however, the results from the study showed that indigenes' suggestions were implemented in most situations $[27,79]$. Though the local customary administration structure considered the settlers as citizens on the traditional area with the same rights and privileges of the indigenes (even with the seat on the traditional council), the Bui Power Authority did not treat the settlers the same way as the indigenes as seen in Table 3. The authority's treatment of the settlers shows that they were viewed through Ollennu's [34] characterization of settlers, and so, the interests of the indigenes were placed above those of the settlers.

Due to the sensitive nature of the exercise of the power of compulsory land acquisition and resettlement, there need to be laws, rules, regulations, as well as plans regarding the process that are made clear and adhered to. The past resettlements had been covered by ad hoc rules formulated by the acquiring authority together with affiliated government departments [61]. This approach was however vacated in the Bui resettlement where the acquiring authority ensured the formulation of a plan prior to the resettlement. There was a further attempt to get the plans to the level of best practice standards, as shown by the World Bank Operational Manual on Involuntary Resettlement (OP/BP 4.12), to avoid the problems of the past resettlements. With respect to the adherence to the laws and regulations, the Lands Commission made sure to apply only the laws of Ghana, which is skewed towards ensuring a quick land acquisition [7,19]. Though Anim-Odame [40] demonstrates the ability of the government to strictly adhere to the $\mathrm{OP} / \mathrm{BP} 4.12$ in other compulsory land acquisition projects. 


\subsection{Accountability}

With respect to accountability, Newell and Wheeler [80] assert that a legitimate accountability claim needs explicit laws or implicit conventions about the responsible accountable body, and the rights and entitlements of the beneficiary could not be ascertained in the results. There was no law governing the resettlement process. The BPA was therefore under no obligation to account directly for the affected persons on matters of the resettlement. The Bui Power Authority (BPA), through its enabling act, was however accountable to the Sector Minister, who in turn is accountable to the national legislature, whose members are directly elected by the people. This long trace of accountability is characterized by Schedler [81] as "the challenge of the n-order accountability" that leads to failure since the second layer of accountability is vulnerable to the same failures as the first.

\section{Conclusions}

This study began with the aim of developing an assessment framework for monitoring good governance at the implementation phase of resettlement activities in customary lands. The study found that transparency, participation and inclusiveness, equity and rule of law and accountability were the relevant good governance principles to resettlement from compulsory land acquisition. The study further found that although the Bui Power Authority (BPA) largely adhered to good governance principles in the implementation of the Bui Dam Project (BDP), other foreseeable factors and circumstances such as the influence of the traditional authorities and the lands commission were not factored into the implementation. Thus, these militated against the application of good governance principles. The process also showed a bottom-up approach to the planning process, but a top-down approach in the implementation phase, with the people being kept ignorant about the happenings, and a resulting non-appreciation of the customary arrangements of the area, resulting in the unequal treatment of indigenes and settlers. This ultimately led to a huge loss of their livelihoods, as well as increased unemployment in the area. The involvement of professionals and the affected persons is not mandatory, and there is no room for the negotiation of the compensation assessment. Compulsory land acquisitions are being conducted in Ghana more often, and resettlement is becoming the preferred form of compensation in rural areas. The results also show an urgent need to review Ghana's laws and policies on compulsory land acquisition. If the negative impacts from the BDP are to be curbed and good governance principles applied, these issues need to be addressed. In conclusion, the developed framework is found to be effective as it can differentiate and isolate the problematic areas between the planning and the implementation phase of the resettlement.

Supplementary Materials: The following are available online at www.mdpi.com/2073-445X/6/4/80/s1.

Author Contributions: This paper is an abridged version of the first author's MSc thesis titled "Governance in Resettlement from Compulsory Land Acquisition: A Case Study of the Bui Dam Project". Kwabena Asiama collected and prepared the data for this research article. Monica Lengoiboni and Paul van der Molen contributed to and supervised the analysis and interpretation of the data. The manuscript was written by Kwabena Asiama, with contributions from Monica Lengoiboni and Paul van der Molen.

Conflicts of Interest: The authors declare no conflict of interest.

\section{Appendix}

Table A1. Results of Good Governance Assessment in the Bui Dam Project.

\begin{tabular}{|c|c|c|c|}
\hline Principle & Thematic Area & Indicator & Score \\
\hline \multirow{4}{*}{ Transparency } & \multirow{4}{*}{ Access to Information } & - Utilization of appropriate media in information provision. & Y \\
\hline & & $\begin{array}{l}\text { - Low level of complexity and bureaucracy in } \\
\text { information provision. }\end{array}$ & Y \\
\hline & & - Establishment of information desk/office. & $\mathrm{N}$ \\
\hline & & $\begin{array}{l}\text { - Free access to information concerning the compulsory land } \\
\text { acquisition and resettlement. }\end{array}$ & Y \\
\hline
\end{tabular}


Table A1. Cont.

\begin{tabular}{|c|c|c|c|}
\hline Principle & Thematic Area & Indicator & Score \\
\hline & & - Full disclosure of the intended use of the property. & Y \\
\hline & & - Laws and regulations are made clear to community members. & $\mathrm{N}$ \\
\hline & & $\begin{array}{l}\text { - Clear and straightforward process of compulsory land acquisition } \\
\text { and resettlement. }\end{array}$ & $\mathrm{N}$ \\
\hline & Openness of Process & $\begin{array}{l}\text { - Compulsory land acquisition process is made clear and spelt out } \\
\text { to community members. }\end{array}$ & $\mathrm{N}$ \\
\hline & & $\begin{array}{l}\text { - Resettlement process is made clear and spelt out to } \\
\text { community members. }\end{array}$ & $\mathrm{Y}$ \\
\hline & & $\begin{array}{l}\text { - Timeline of the process should be made available to the } \\
\text { affected persons. }\end{array}$ & $\mathrm{N}$ \\
\hline \multirow{8}{*}{$\begin{array}{l}\text { Public Participation } \\
\text { and Inclusiveness }\end{array}$} & \multirow{3}{*}{ Involvement of Actors } & - Inclusion of the people's representatives in the process. & Y \\
\hline & & - High involvement of the local population in the processes. & $\mathrm{N}$ \\
\hline & & $\begin{array}{l}\text { - Frequent interaction between the local people/their } \\
\text { representatives and the acquiring authority. }\end{array}$ & $\mathrm{N}$ \\
\hline & \multirow{5}{*}{ Decision-making Process } & - Possibility of the lodging complaints/making suggestions. & Y \\
\hline & & - People's complaints/suggestions responded to. & $\mathrm{N}$ \\
\hline & & - Ability of the people to reject plans by the acquiring authority. & $\mathrm{N}$ \\
\hline & & $\begin{array}{l}\text { Explore other options of land acquisition apart from compulsory } \\
\text { land acquisition. }\end{array}$ & $\mathrm{N}$ \\
\hline & & $\begin{array}{l}\text { Involvement of community members in resettlement } \\
\text { allocation process. }\end{array}$ & $\mathrm{N}$ \\
\hline \multirow{12}{*}{$\begin{array}{l}\text { Equity and Rule } \\
\text { of Law }\end{array}$} & \multirow{8}{*}{$\begin{array}{l}\text { Fair and Adequate } \\
\text { Compensation } \\
\text { And Tenure Security }\end{array}$} & - Independent valuation of assets. & $\mathrm{N}$ \\
\hline & & - Prompt payment of compensation. & $\mathrm{N}$ \\
\hline & & - Fair and adequate compensation. & $\mathrm{N}$ \\
\hline & & - The voice of the people regarding the choice of compensation. & $\mathrm{N}$ \\
\hline & & $\begin{array}{l}\text { - The ability of the affected persons to hire professionals to assist } \\
\text { in decision-making. }\end{array}$ & $\mathrm{N}$ \\
\hline & & $\begin{array}{l}\text { - Compensation values are negotiated between the acquiring } \\
\text { authority and the affected persons. }\end{array}$ & $\mathrm{N}$ \\
\hline & & - Compensate all affected persons including those without titles. & Y \\
\hline & & - Equal or better tenure security. & Y \\
\hline & \multirow{4}{*}{$\begin{array}{l}\text { Livelihood and Equal } \\
\text { Treatment of Parties, } \\
\text { and Rule of Law }\end{array}$} & $\begin{array}{l}\text { - Formulation of and adherence to plans for } \\
\text { livelihood rehabilitation. }\end{array}$ & $\mathrm{N}$ \\
\hline & & - Settlers are treated the same as indigenes. & $\mathrm{N}$ \\
\hline & & - The existence of laws and regulations governing the process. & $\mathrm{N}$ \\
\hline & & - $\quad$ Adherence to the laid down laws and regulations. & Y \\
\hline \multirow{7}{*}{ Accountability } & \multirow{3}{*}{$\begin{array}{l}\text { Assignment of } \\
\text { Responsibilities }\end{array}$} & - Clear assignment of responsibilities. & $\mathrm{Y}$ \\
\hline & & - Appropriateness of the responsibility assignment. & Y \\
\hline & & - Participatory manner of selecting representatives. & Y \\
\hline & \multirow{4}{*}{$\begin{array}{l}\text { Accountability } \\
\text { Arrangement }\end{array}$} & $\begin{array}{l}\text { - Existence of body to horizontally and vertically check } \\
\text { the authority. }\end{array}$ & $\mathrm{N}$ \\
\hline & & - Justification of the decisions of the acquiring authorities. & $\mathrm{N}$ \\
\hline & & $\begin{array}{l}\text { Effectiveness of civil society and the media in mobilizing demand } \\
\text { for accountability. }\end{array}$ & $\mathrm{N}$ \\
\hline & & - Sanctions for unaccountability. & $\mathrm{N}$ \\
\hline
\end{tabular}

\section{References}

1. Cernea, M.M. Compensation and benefit sharing: Why resettlement policies and practices must be reformed. Water Sci. Eng. 2008, 1, 89-120. [CrossRef] 
2. Arnall, A.; Thomas, D.S.G.; Twyman, C.; Liverman, D. Flooding, Resettlement, and Change in Livelihoods: Evidence from Lural Mozambique. Disasters 2013, 37, 468-488. [CrossRef] [PubMed]

3. De Wet, C. The Experience with Dams and Resettlement in Africa. World Comm. Dams 2000, 1, 171-183.

4. Okuku, E.O.; Bouillon, S.; Ochiewo, J.O.; Munyi, F.; Kiteresi, L.I.; Tole, M. The impacts of hydropower development on rural livelihood sustenance. Int. J. Water Resour. Dev. 2016, 32, 267-285. [CrossRef]

5. Bartolome, L.J.; de Wet, C.; Mander, H.; Nagraj, V.K. Displacement, Resettlement, Rehabilitation, Reparation, and Development; WCD Thematic Review; Secretariat of the World Commission on Dams: Cape Town, South Africa, 2000.

6. Syagga, P.M.; Olima, W.H.A. The Impact of Compulsory Land Acquisition on Displaced Households. Habitat Int. 1996, 20, 61-75. [CrossRef]

7. Larbi, W.O.; Antwi, A.; Olomolaiye, P. Compulsory Land Acquisition in Ghana-Policy and Praxis. Land Use Policy 2004, 21, 115-127. [CrossRef]

8. Hensengerth, O. Interaction of Chinese Institutions with Host Governments in Dam Construction: The Bui Dam in Ghana. In Evolution of Dam Policies; Scheumann, W., Hensengerth, O., Eds.; Springer: Berlin/Heidelberg, Germany; New York, NY, USA, 2014; pp. 229-271.

9. Raschid-Sally, L.; Akoto-Danso, E.K.; Kalitsi, E.A.K.; Ofori, B.D.; Koranteng, R.T. The Resettlement Experience of Ghana Analyzed via Case Studies of the Akosombo and Kpong Dams. In Proceedings of the 9th Annual Symposium on Poverty Research, Colombo, Sri Lanka, 2 December 2008.

10. Owusu, K.; Obour, P.B.; Nkansah, M.A. Downstream effects of dams on livelihoods of river-dependent communities: The case of Ghana's Kpong Dam. Geografisk Tidsskrift J. Geogr. 2017, 117, 1-10. [CrossRef]

11. Urban, F.; Nordensvard, J.; Siciliano, G.; Li, B. Chinese Overseas Hydropower Dams and Social Sustainability: The Bui Dam in Ghana and the Kamchay Dam in Cambodia. Asia Pac. Policy Stud. 2015, 2, 573-589. [CrossRef]

12. Owen, J.R.; Deanna, K. Mining-induced displacement and resettlement: A critical appraisal. J. Clean. Prod. 2015, 87, 478-488. [CrossRef]

13. Yankson, P.W.K.; Asiedu, A.B.; Owusu, K.; Urban, F.; Siciliano, G. The Livelihood Challenges of Resettled Communities of the Bui Dam Project in Ghana and the Role of Chinese Dam-builders. Dev. Policy Rev. 2017. [CrossRef]

14. Naab, F.Z.; Nunbogu, A.M.; Dinye, R.D.; Dongzagla, A. Resettlement and Livelihood Sustainability in Sub-Saharan Africa: The Case of Bui Hydro-Power Dam Project, Ghana. World Acad. Sci. Eng. Technol. Int. J. Soc. Behav. Educ. Econ. Bus. Ind. Eng. 2016, 10, 1780-1788.

15. Obour, P.B.; Owusu, K.; Agyeman, E.A.; Ahenkan, A.; Madrid, À.N. The impacts of dams on local livelihoods: A study of the Bui Hydroelectric Project in Ghana. Int. J. Water Resour. Dev. 2016, 32, 286-300. [CrossRef]

16. Atindana, S.A.; Mensah, P.; Alhassan, E.H.; Ampofo-Yeboah, A.; Abobi, S.M.; Akongyuure, D.N.; Abarike, E.D. The Socio-Economic Impact of Bui Dam on Resettled Communities; A Case Study of Lucene and Agbegikuro Communities in the Northern Region of Ghana. UDS Int. J. Dev. 2015, 2, 45-51.

17. Mettle, M. Forced Resettlement in Ghana; Norwegian University of Science and Technology: Trondheim, Norway, 2011.

18. Otu-Tei, C. Broken Promises: Ghana's Bui Dam Resettlement; World Rivers Review: Berkeley, CA, USA, March 2014.

19. Asiama, K.O. Governance in Resettlement from Compulsory Land Acquisition and Resettlement: A Case Study of the Bui Dam Project. Master's Thesis, University of Twente, Enschede, The Netherlands, 2015.

20. UNDP. Governance for Sustainable Human Development; United Nations Development Programme: New York, NY, USA, 1997.

21. Food and Agriculture Organisation (FAO). Good Governance in Land Tenure and Administration. FAO Land Tenure Studies 9; Food and Agriculture Organisation: Rome, Italy, 2007.

22. World Bank. Strengthening World Bank Group Engagement on Governance and Anticorruption; Joint Ministerial Committee of the Boards of Governers of the World Bank and the Fund on the Transfer of Real Resources to Developing Countries: Washington, DC, USA, 2007.

23. Bell, K.C. Good Governance in Land Administration; Responding to Global Agenda-FIG Working Paper; FIG: Helsinki, Finland, 2007.

24. Zakout, W.; Wehrmann, B.; Torhonen, M.-P. Good Governance in Land Administration; World Bank: Washington, DC, USA, 2006.

25. Parigi, V.; Geeta, P.; Kailasam, R. Ushering in Transparency for Good Governance; Centre for Good Governance: Hyderabad, India, 2004. 
26. Abubakari, Z.; van der Molen, P.; Bennett, R.; Kuusaana, E.D. Land consolidation, customary lands, and Ghana's Northern Savannah Ecological Zone: An evaluation of the possibilities and pitfalls. Land Use Policy 2016, 54, 386-398. [CrossRef]

27. Arko-Adjei, A. Adapting Land Administration to the Institutional Framework of Customary Tenure. Ph.D. Thesis, Delft University of Technology, Delft, The Netherlands, 2011.

28. Asiama, S.O. Current Changes in Customary/Traditional Land Delivery Systems in Sub-Saharan African Cities-Ghana. In Housing the Poor through African Neo-Customary Land Delivery Systems; Mattingly, M., Durand-Lasserve, A., Eds.; DFID: London, UK, 2004; pp. 41-57.

29. Hardin, G. The Tragedy of the Commons. Science 1968, 162, 1243-1248. [CrossRef] [PubMed]

30. Van Gils, H.; Siegl, G.; Bennett, R. The living commons of West Tyrol, Austria: Lessons for land policy and land administration. Land Use Policy 2014, 38, 16-25. [CrossRef]

31. Asiama, K.O.; Bennett, R.; Zevenbergen, J. Land Consolidation for Sub-Saharan Africa's Customary Lands-The Need for Responsible Approaches. Am. J. Rural Dev. 2017, 5, 39-45.

32. Adu-Gyamfi, A. An Overview of Compulsory Land Acquisition in Ghana: Examining Its Applicability and Effects. Environ. Manag. Sustain. Dev. 2012, 1, 187-203. [CrossRef]

33. Kasanga, K.R.; Kotey, N.A. Land Management in Ghana: Building on Tradition and Modernity; International Institute for Environment and Development: London, UK, 2001.

34. Ollennu, N.A. Principles of Customary Land Law in Ghana; Sweet and Maxwell: London, UK, 1962.

35. Asiama, K.O.; Bennett, R.M.; Zevenbergen, J.A. Participatory Land Administration on Customary Lands: A Practical VGI Experiment in Nanton, Ghana. ISPRS Int. J. Geo-Inf. 2017, 6, 186. [CrossRef]

36. Asiama, S.O. Crossing the Barrier of Time. The Asante Woman in Urban Land Development. Africa Rivista Trimestrale di Studi e Documentazione dell'Istituto Italiano per l'Africa e l'Oriente 1997, 52, 212-236.

37. Asiama, K.O.; Bennett, R.M.; Zevenbergen, J.A. Land consolidation on Ghana's rural customary lands: Drawing from The Dutch, Lithuanian and Rwandan experiences. J. Rural Stud. 2017, 56, 87-99. [CrossRef]

38. Boni, S. Indigenous Blood and Foreign Labor: The Ancestralization of Land Rights in Sefwi (Ghana). In Land and the Politics of Belonging in West Africa; Kuba, R., Lentz, C., Eds.; Brill Academic Pub: Boston, MA, USA, 2006; pp. 161-186.

39. Berry, S. Ancestral Property: Land, Politics and 'the Deeds of the Ancestors' in Ghana and Côte d'Ivoire. In Contesting Land and Custom in Ghana; Ubink, J.M., Amanor, K.S., Eds.; Leiden University Press: Leiden, The Netherlands, 2008; pp. 27-54.

40. Anim-Odame, W.K. Compulsory Acquisition and Compensation in Ghana: Principles and Practice. In American Real Estate Society Conference; American Real Estate Society: Seattle, WA, USA, 2011.

41. Parliament of Ghana. Constitution of Ghana; Ghana Publishing Company: Accra, Ghana, 1992.

42. Van Eerd, M.; Banerjee, B. Evictions, Acquisition, Expropriation and Compensation: Practices and Selected Case Studies; Global Land Tool Network: Nairobi, Kenya, 2013.

43. Cernea, M.M. Involuntary Resettlement in Development Projects; The World Bank: Washington, DC, USA, 1988.

44. The World Bank. Involuntary Resettlement Sourcebook_Planning and Implementation in Development Projects; The World Bank: Washington, DC, USA, 2004.

45. Asian Development Bank. Handbook on Resettlement: A Guide to Good Practice; Asian Development Bank: Manila, Philippines, 1998.

46. Alias, A.; Daud, N.M. Payment of Adequate Compensation for Land Acquisition in Malaysia. Pac. Rim Prop. Res. J. 2006, 12, 326-349. [CrossRef]

47. Shapiro, E.; Mackmin, D.; Sams, G. Modern Methods of Valuation; Taylor and Francis: Hoboken, NJ, USA, 2012.

48. Schmidt-Soltau, K.; Brockington, D. Protected Areas and Resettlement: What Scope for Voluntary Relocation? World Dev. 2007, 35, 2182-2202. [CrossRef]

49. German, L.; Schoneveld, G.; Mwangi, E. Processes of Large-Scale Land Acquisition by Investors: Case Studies from Sub-Saharan Africa; Center for International Forestry Research (CIFOR): Bogor, Indonesia, 2011.

50. WCD. Dams and Development-A Framework for Decision-Making; Earthscan Publications Ltd.: London, UK; Sterling, VA, USA, 2000.

51. Van der Molen, P.; Tuladhar, A.M. Corruption and Land Administraton. In Proceedings of the Shaping the Change, XXIII FIG Congress, Munich, Germany, 8-13 October 2006.

52. Deininger, K.; Selod, H.; Burns, A. The Land Governance Assessment Framework: Identifying and Monitoring Good Practice in the Land Sector; The World Bank: Washington, DC, USA, 2012. 
53. Birkinshaw, P. Transparency as a Human Right. In Transparency: The Key to Better Governance? Hood, C., Heald, D., Eds.; Oxford University Press: Oxford, UK, 2006; pp. 47-58.

54. Mostert, E. The Challenge of Public Participation. Water Policy 2003, 5, 179-197.

55. Ty, P.; van Westen, A.C.M.; Zoomers, A. Compensation and Resettlement Policies after Compulsory Land Acquisition for Hydropower Development in Vietnam: Policy and Practice. Land 2013, 2, 678-704. [CrossRef]

56. United Nations. United Nations Declaration on the Rights of Indigenous Peoples; United Nations: New York, NY, USA, 2008.

57. United Nations Human Rights. Free, Prior and Informed Consent of Indigenous Peoples; United Nations Human Rights: Geneva, Switzerland, 2013.

58. Singer, J.; Pham, H.T.; Hoang, H. Broadening stakeholder participation to improve outcomes for dam-forced resettlement in Vietnam. Water Resour. Rural Dev. 2014, 4, 85-103. [CrossRef]

59. Curry, N. Rights of Access to Land for Outdoor Recreation in New Zealand: Dilemmas Concerning Justice and Equity. J. Rural Stud. 2001, 17, 409-419. [CrossRef]

60. Magadza, C.H.D. Social Impacts of the Creation of Lake Kariba. In Involuntary Resettlement in Africa; Cook, C.C., Ed.; World Bank: Washington, DC, USA, 1994.

61. Chambers, R. The Volta River Experience; Pall Mall Press Ltd.: London, UK, 1970.

62. Dicey, A. Introduction to the Study of the Law of the Constitution; Macmillan: London, UK, 1897.

63. Licht, A.N.; Goldschmidt, C.; Schwartz, S.H. Culture rules: The Foundations of the Rule of Law and other Norms of Governance. J. Comp. Econ. 2007, 35, 659-688. [CrossRef]

64. FAO. Compulsory Acquisition of Land and Compensation. FAO Land Tenure Studies 10; Food and Agriculture Organisation: Rome, Italy, 2009.

65. Viitanen, K.; Falkenbach, H.; Nuuja, K. Compulsory Purchase and Compensation: Recommendations for Good Practice; International Federation of Surveyors: Copenhagen, Denmark; FIG: Helsinki, Finland, 2010.

66. Graham, J.; Amos, B.; Plumptre, T. Governance Principles for Protected Areas in the 21st Century; Institute on Governance: Ottawa, ON, Canada, 2003.

67. Yin, R.K. Case Study Research: Design and Methods; Sage Publications: Thousand Oaks, CA, USA, 2003.

68. ERM (Environmental Resources Management). Resettlement Policy Framework; Environmental Resources Management: London, UK, 2007.

69. Ghana Statistical Service (GSS). Digest of Macroeconomic Data; Ghana Statistical Service (GSS): Accra, Ghana, 2011.

70. UN-Habitat. Tools to Support Transparency in Land Administration; UN-Habitat: Nairobi, Kenya, 2013.

71. UN-Habitat. Count Me in: Surveying for Tenure Security and Urban Land Management; UN-Habitat: Nairobi, Kenya, 2010.

72. Ubink, J.M.; Quan, J.F. How to combine tradition and modernity? Regulating customary land management in Ghana. Land Use Policy 2008, 25, 198-213. [CrossRef]

73. Juul, K.; Lund, C. Negotiating Property in Africa; Heinemann: Portsmouth, UK, 2002.

74. McEwan, C. 'Bringing Government to the People': Women, Local Governance and Community Participation in South Africa. Geoforum 2003, 34, 469-481. [CrossRef]

75. Smith, B. Public Policy and Public Participation Engaging Citizens and Community in the Development of Public Policy; Health Canada: Ottawa, ON, Canada, 2003.

76. Parliament of Ghana. Minerals and Mining (Compensation and Resettlement) Regulations (L.I. 2175); Parliament of Ghana: Accra, Ghana, 2012.

77. Parliament of Ghana. State Lands Act, 1962 (Act 125); Parliament of Ghana: Accra, Ghana, 1962.

78. Kusiluka, M.M.; Kongela, S.; Kusiluka, M.A.; Karimuribo, E.D.; Kusiluka, L.J.M. The Negative Impact of Land Acquisition on Indigenous Communities' Livelihood and Environment in Tanzania. Habitat Int. 2011, 35, 66-73. [CrossRef]

79. Gyapong, P. Assessing Customary Land Tenure Institutions for Land Administration in Ghana: Good Governance Perspective. Master's. Thesis, University of Twente, Enschede, The Netherlands, 2009. 
80. Newell, P.; Wheeler, J. Rights, Resources and the Politics of Accountability; Zed Books: London, UK, 2006.

81. Schedler, A. Conceptualizing Accountability. In The Self-Restraining State: Power and Accountability in New Democracies; Schedler, A., Diamond, L., Plattner, M., Eds.; Lynne Rienner: London, UK, 1999; pp. 13-28.

(C) 2017 by the authors. Licensee MDPI, Basel, Switzerland. This article is an open access article distributed under the terms and conditions of the Creative Commons Attribution (CC BY) license (http://creativecommons.org/licenses/by/4.0/). 